\title{
PERAN ORANG TUA DALAM MENINGKATKAN KUALITAS PENYAMPAIAN MATERI GURU MELALUI MEDIA BELAJAR VIA DARING
}

\author{
I Made Ardika Yasaa, Yuyun Dewi Kartikab, Gusti Ayu Sintya Widi Cahyanic \\ abcInstitut Agama Hindu Negeri Gde Pudja Mataram \\ e-mail: a kpjm.ardika@gmail.com ${ }^{\mathrm{b}}$ ayusintya115@gmail.com \\ cyuyundewi667@gmail.com
}

(Diterima: 25 Januari 2022; Direvisi: 27 Januari 2022; Diterbitkan: 31 Januari 2022)

\begin{tabular}{l}
\hline Keywords: \\
\hline Parental Role, \\
quality, Learning \\
Media, Offline \\
\end{tabular}

Kata kunci:

Peran Orang Tua,Kualitas,Me dia Belajar, Luring
Abstract
This research related to the role of parents in improving the quality of teacher material delivery through offline learning media was carried out with the objectives of 1 . To understand the role of parents during Covid-19, 2. To know the media and learning resources during Covid-19, 3. To analyze the role of people know in delivering teacher material during Covid-19. The Covid-19 pandemic has forced the government to carry out several emergency policies, one of which is Learning From Home (BDR). In this BDR activity, parents become a bridge of knowledge from teacher to child, so parents play an important role in online learning. Parents and teachers are expected to have good communication so that teaching and learning activities for children are not disturbed and can run. The government is expected to pay attention to the obstacles experienced by students, teachers, and parents

\begin{tabular}{l} 
Abstrak \\
\hline Penelitian terkait peran orang tua dalam \\
meningkatkan kualitas penyampaian materi guru \\
melalui media belajar via luring ini dilaksanakan \\
dengan tujuan 1. Untuk memahami peran orang tua \\
selama Covid-19, 2.Untuk mengatahui media dan \\
sumber belajar selama Covid-19, 3.Untuk menganalisis \\
peran orang tau dalam menyampaikan materi guru \\
selama Covid-19. Pendemi Covid-19 membuat \\
pemerintah harus melakukan beberapa kebijakan \\
darurat salah satunya adalah Belajar Dari Rumah \\
(BDR). Dalam kegiatan BDR ini, orang tua menjadi \\
jembatan pengetahuan dari guru ke anak, sehingga
\end{tabular}


orang tua berperan penting dalam pembelajaran via daring. Orang tua dan guru diharapkan memiliki komunikasi yang baik sehingga kegiatan belajar mengajar anak tidak terganggu dan dapat berjalan. Pemerintah diharapkan dapat memperhatikan kendala-kendala yang dialami oleh siswa, guru, dan orang tua.

\section{PENDAHULUAN}

Menurut Undang-undang No. 20 Tahun 2003 tentang SISDIKNAS. Pendidikan ialah segala usaha dan upaya secara sadar, terencana dan sistematis dengan tujuan Agar dapat mewujudkan situasi belajar yang nyaman dan kegiatan pembelajaran yang berjalan dengan lancar sehingga siswa mampu secara aktif menggali potensi yang dimiliki sehingga memiliki potensi kecerdasan, kekuatan dari segi spiritual keagamaan, keperibadian, pengendalian diri sehingga memiliki akhlak mulia, dan keterampilan yang diperlukan oleh siswa itu sendiri, masyarakat, bangsa dan negara.

Pada tahun 2019 muncul virus yang mengemparkan dunia, dan bertahan sampai sekarang. Virus ini juga masuk ke negara Indonesia, sehingga Indonesia membuat kebijakan baru dimana didalam dunia pendidikan yang pada umumnya dilaksanakan secara tatap muka dikelas namun karena situasi dan kondisi pandemic ini maka kegiatan pembelajaran dilakukan secara daring.

Menurut KH. Lalu Gede (2020), dalam jurnalnya yang berjudul Transformasi Media Pembelajaran Pada Masa Pandemi Covid-19.
Menyatakan bahwa situasi Pandemi Covid-19 memiliki dampak yang sangat signifikan mempengaruhi berbagai sektor, salah satunya ialah sektor pendidikan. Seperti yang telah kita bersama ketahui Dunia pendidikan juga terkena dampak dari situasi pandemi ini. Hal itu menuntuk kesigapan seorang pendidik dan tenaga kependidikan dalam memfasilitasi kegiatan pembelajaran, seorang Pendidik bertanggungjawab terhadap kelancaran kegiatan belajar-mengajar, walaupun kondisinya dalam kegiatan belajar-mengajar siswa tidak tatap muka secara langsung dikelas namun secara daring dirumah masing-masing. Seorang Pendidik harusnya memiliki inisatif dan ide kreatif untuk menggunakan alat maupun aplikasi dalam mendesain media pembelajaran sebagai bentuk inovasi yaitu dengan memanfaatkan segala fasilitas yang dimiliki untuk menunjang pembelajaran secara online.

Hal ini senada dengan keputusan MENDIKBUD RI terkait Surat Edaran Nomor 4 Tahun 2020 tentang Pelaksanaan Kebijakan Pendidikan dalam Masa Darurat Penyebaran Corona Virus Disease (Covid-19). Sehingga proses pembelajaran dapat dilakukan melalui 
sistem daring sehingga pelaksanaan pembelajaran menggunakan beberapa jenis alat bantu elektronik seperti komputer atau laptop maupun telepon genggam yang tentunya dapat mengakses aplikasi yang terhubung jaringan internet. Dengan kondisi ini guru bisa melaksanakan kegiatan pembelajaran secara bersama pada waktu yang sama dengan memanfaatkan aplikasi grup di media sosial seperti aplikasi zoom, WhatsApp (WA), instagram, telegram, ataupun media lainnya sebagai media pembelajaran. Dengan adanya fasilitas aplikasi tersebut maka pendidik dapat memastikan agar peserta didik aktiv mengikuti proses pembelajaran secara online pada waktu bersamaan, walaupun di tempat yang berbeda. Selain itu Guru juga dapat memberi penugasan kepada siswa walau tidak bertemu secara langsung sesuai dengan tujuan materi yang disampaikan kepada siswa.

Namun, hal yang sering terjadi ialah kasus ketika guru memberikan penugasan kepada siswa secara online terkadang bukan siswa yang mengerjakan tugas tersebut melainkan orang tuanya, dan hal yang sering terjadi ialah ketika penerapan pembelajaran via daring ini terjadi ialah ketidak merataan atas kepemilikan perangkat aplikasi online seperti ponsel pintar berbasis android yang dialami oleh siswa dan tidak semua siswa dan orang tua siswa memiliki kemampuan, keterampilan untuk mengakses informasi melalui media online, dan mirisnya keterbatasan kemampuan orang tua peserta didik untuk membeli kouta internet mempengaruhi presensi kehadiran peserta didik dalam kegiatan belajar, serta terkadang sebagianbesar siswa kendala masalah sinyal bagi siswa yang tinggal ditempat yang terpencil, selain itu sebagian besar orangtua siswa memiliki kondisi ekonomi pas-pasan, dan proses pembelajaran kurang terkontrol hal ini dikarenakan proses pembelajaran secara tidak langsung tatap muka.

Dalam hal ini bukan hanya guru sebagai pendidik yang berperan penting untuk merencanakan proses pendidikan tetap berjalan. Namun dukungan dan partisipasi orang tua dibutuhkan dalam hal ini, karena seluruh kegiatan pendidikan dilakukan secara online atau belajar dari rumah (BDR). Berdasarkan pemaparan diatas maka peran orang tua dirasa sangat besar pengaruhnya untuk menyampaikan kembali atas materi yang telah diberikan oleh pendidik melalui media dan sumber belajar via daring. Maka peneliti menganggap penelitian tentang "Peran Orang Tua Dalam Meningkatkan Kualitas Penyampaian Materi Guru Melalui Media Belajar Via daring". Dirasa sangat penting untuk diteliti.

\section{METODE}

Penelitian ini menggunakan metode deskriptif kualitatif yaitu penelitian yang proses pengambilan data dan pengumpulan data melalui 
langkah observasi, wawancara, dan dokumentasi. Seperti pada umumnya bahwa metode deskriptif fokus penjelasannya ialah objek penelitian, dimana penelitian yang berjudul “Peran Orang Tua Dalam Meningkatkan Kualitas Penyampaian Materi Guru Melalui Media Belajar Via daring" ini obyek penelitiannya adalah orang tua siswa dimana yang menjadi sampelnya ialah orang tua peserta didik yang sekolah di Pendidikan Anak Usia Dini (PAUD) di kota Mataram. Penelitian ini seperti halnya penelitian deskriptif lainnya tentunya memiliki suatu tujuan pokok yang dapat memberikan penjelasan dan gambaran terkait suatu fenomena yang diteliti.

Dalam penelitian kualitatif ini peneliti menggunakan tehnik wawancara, observasi dan dokumentasi sebagai alat bantu mengumpulkan data dari responden baik melalui pengamatan langsung,dan pengajuan pertanyaan sehingga dalam kegiatan tersebut peneliti hendaknya tetap siap sedia pulpen, kertas untuk mencatat dan handphone android ataupun tape recorder untuk merekam percakapan tersebut. Dalam pelaksanaan pengumpulan data dengan menggunakan jenis instrumen observasi, peneliti memilih jenis observasi non-partisipan pada kegiatan pengamatan namun peneliti tidak termasuk didalam anggota kelompok yang akan jadi obyek maupun subyek pengamatan dengan tujuan agar hasil observasi lebih memenuhi standar kelayakan karena tidak bersifat bias.
Dalam kegiatan pengumpulan data dalam bentuk dokumentasi peneliti mengumpulkan dokumen-dokumen maupun gambar yang terkait dalam ranah penelitian yang dilaksanakan yang akan menjadi data sekunder dalam penelitian.

\section{PEMBAHASAN}

\section{A. Peran Orang Tua dalam Pembelajaran}

Valeza (2017) mengatakan bahwa pada situasi masa covid-19 ini tanggungjawab orang tua bertambah selain dari segi mencari nafkah dn mengurus rumah tangga juga diberikat tugas utama dalam bidang pendidikan yaitu memberikan segala fasilitas yang memadai dalam kegiatan pembelajaran dirumah sebab pada masa covid-19 prosentase kegiatan belajar lebih besar untuk dilaksanakan dirumah sehingga orang tua harus memantau proses belajar anak dirumah sehingga walau kegiatan pembelajaran telah dilakukan secara luring maka orang tua harus tetap memantau kesiapan anak untuk memulai suatu pembelajaran via luring. Sebab peran orang tua sangat dibutuhkan guna membentuk skema alur yang dapat menuntun anak meraih masa depan yang cerah dari segi bidang pendidikan. Walaupun istilahnya pendidikan di luar keluarga, namun bukan berarti orang tua melepas tanggung jawab terhadap pendidikan anak-anaknya, tetapi harusnya hal itu menjadi suatu pemacu semangat orang tua dalam mendukung, memfasilitasi kegiatan pembelajaran anak walaupun orangtua siswa memiliki keterbatasan dari segi 
ilmu pengetahuan, keterampilan ataupun pengalaman dalam mengajar sebab mengajar ialah suatu profesi dan seni harus memiliki pengetahuan, keterampilan, dan ilmu dalam proses pendidikan sebab orang yang sudah memiliki legalitas dalam mengajarpun belum tentu memiliki keterampilan dalam mengajar walau memiliki ilmu dan pengetahuan terkait bidang keahliannya dalam mengampu suatu mata pelajaran. Adapun bekal yang hendaknya harus dimiliki orang tua dalam proses berperan aktiv dalam kegiatan pendidikan ialah, keterampilan dalam menarik minat anak agar termotivasi untuk bersemangat mengikuti proses belajar, sebab sebagaimanapun pintarnya orang tua, tingginya ilmu pengetahuan orang tua jika tidak dapat menarik minat anaknya belajar maka ia akan jagal dalam mengarahkan anaknya pada proses ataupun kegiatan pembelajaran dan orang tua siswa harus memahami bahwa sifat ilmu searah dengan perkembangan zaman. Sehingga segala keterbatasan yang dimiliki oleh orang tua seolah-olah didesak untuk diminimalisir. Sudah waktunya bahwa Orang tua akan memiliki suatu pekerjaan ataupun tugas tambahan didalam menjalani kehidupan sehari-hari yaitu sebagai guru dalam lingkungan keluarga sehingga dituntut untuk bertanggung jawab terhadap anggota keluarganya. Sehingga secara tidak langsung orang tua memiliki kewajiban untuk berusaha kebutuhan sandang, pangan, papan,kesehatan dan ditambah kebutuhan pendidikan, jika hal itu terpenuhi maka anak akan mampu untuk hidup sendiri.

Demikian halnya menurut Nur Afni dan Jumahir (2020), mengatakan bahwa peran keluarga sebagai media utama dalam pendidikan bagi perkembangan siswa harusnya tetap mengembangkan segala potensi yang dimiliki baik dari segi potensi jasmani ataupun potensi rohani yang dimiliki secara optimal melalui program peningkatan peran lingkungan keluarga sebagai lingkungan pendidikan. Adapun penjabaran atas beberapa peran yang dimaksud tersebut ialah: memperhatikan perkembangan maupun kemajuan yang dialami oleh anaknya, orang tua hendaknya ikut terlibat pada setiap kegiatan belajar anaknya, orang tua harusnya mampu menciptakan suatu suasana belajar yang kondusif, tenang dan nyaman, orang tua siswa mampu memberikan suatu bimbingan dalam kegiatan belajar, dan orang tua siswa hendaknya memberikan penyegaran dan motivasi yang dapat membangkitkan semangat belajar kepada anaknya. Prestasi belajar ialah suatu kemampuan yang dimiliki siswa dalam rangka tujuan mencapai penyerapan materi pelajaran tertentu yang telah ditetapkan secara sistematis terukur dan terarah sesuai dengan dasar pedoman kurikulum, waktu, dan kriteria yang telah ditentukan. Suatu faktor yang sangat signifikan mempengaruhi Prestasi belajar siswaialah faktor eksternal yaitu faktor dari luar dirinya. Sehingga hakikat Pencapaian suatu prestasi tidak luput dari hasil interaksi siswa dengan 
lingkungan keluarga dan lingkungan tempat siswa bersekolah yang merupakan pusat pendidikan.

Adapun hal yang orang tua harus penuhi untuk menunjang kegiatan belajar anaknya agar dapat meraih prestasi yaitu;

\section{Kebutuhan sekolah Anak}

Setiap orang tua tentunya sudah memahami bahwa kebutuhan sekolah anak ialah merupakan tanggungjawab utamanya Kebutuhan sekolah anak, meliputi segala peralatan dan biaya yang dibutuhkan dalam menunjang kegiatan belajar. Peralatan pokok anak untuk kegiatan belajar disekolah ialah buku tulis, buku gambar, alat tulis, alat menggambar, buku-buku materi pelajaran sekolah, tas, dan lain sebagainya. Biaya dan peralatan sekolah yang merupakan kebutuhan sekolah anak yang wajib untuk dipenuhi tersebut tak bisa dikatakan murah namun bersifat relative jika hal itu dikaitkan dengan faktor ekonomi orang tua siswa, dengan demikian orang tua harus sigap dan menyiapkan alternative untuk mengatasi masalah tersebut yaitu misalnya dengan cara menabung ataupun dengan mengikuti program asuransi pendidikan sejak anaknya belum memasuki jenjang sekolah.

\section{Intensitas pendampingan anak saat belajar di rumah.}

Setiap anak memiliki daya serap yang berbeda atas materi yang diterima disekolah baik secara daring maupun luring sebab didalam proses belajar mengajar sering terdapat distorsi dalam penerimaan maupun penyampaian informasi dari pendidik kepada peserta didik. Ada beberapa Anak yang terkadang sulit secara langsung untuk memahami suatu bahan pelajaran yang diberikan oleh guru, disebabkan oleh beberapa faktor baik dari faktor internal yaitu karena keterbatasan kemampuan siswa dalam menyerap materi karena kemampuannya menerima stimulus dari pendidik dan karena daya ingat yang kurang dan faktor eksternalnya ialah karena guru tidak memiliki kemampuan yang memadai dalam menyampaikan materi entah karena faktor public speakingnya yang kurang atau keterampilannya dalam menggunakan media dan sumber belajar yang kurang. Hal itu akan mempengaruhi penerimaan materi anak di sekolah maka dengan demikian orang tua diharapkan dapat membantu dalam hal menuntaskan masalah yang dihadapi tersebut saat anak sudah tiba di rumah, dengan cara memberikan pendampingan kepada si anak dalam hal mengulas kembali materi yang telah diajarkan disekolah dan orang tua membantu si anak untuk mengerti bahan pelajaran yang belum dipahami saat belajar disekolah.

\section{Motivasi Anak untuk meraih cita- citanya melalui pendidikan.}

Melain memberikan pendampingan anak dirumah orang tua harus memiliki trik dan cara ataupun strategi untuk dapat membangkitkan semangat belajar anak, memberikan suatu motivasi baik dalam bentuk reward ataupun prestise pada setiap pencapaian prestasi anak 
hal itu dilakukan demi kelangsungan anak dalam menjalani pendidikan formal. Sebab pendidikan formal merupakan faktor sangat penting untk anak dalam rangka mewujudkan citacita dan impiannya. Orang tua harus mampu memberikan arahan serta bimbingan sehingga dapat termotivasi untuk mewujudkan cita-cita yang diimpikannya. Contohnya: "Adek kan cita-citanya jadi dokter ya? Kalau Adek ingin jadi seorang dokter, Adek harus rajin belajar dan bersekolah, agar Adek jadi anak yang pintar, kalua adik udah pintar nanti cita-cita Adek tercapai". Selain memberikan kata-kata motivasi orang tua harusnya memberikan reward baik dalam bentuk hadiah berupa materi ataupun prestise dalam bentuk pujian kepada anak setiap anak dapat menghasilkan suatu perubahan kearah yang positif.

\section{Suasana nyaman dalam belajar.}

Salah satu kunci utama agar anak betah dalam mengikuti kegiatan belajar dan mengajar ialah suasana ruangan yang kondusif dan nyaman maka inisiatif orang tua untuk menciptakan suasana nyaman, tenang khususnya ruang belajar anak agar anak dapat fokus serta konsentrasi saat melakukan aktivitas belajar sangat dibutuhkan, contohnya: hindarkan segala sesuatu aksesoris ruang belajar yang dapat menimbulkan distorsi dalam kegiatan belajar misal radio, televisi, dan pengaturan cahaya ruangan sangat diperlukan oleh karena itu setinglah pencahayaan para ruang belajar anak dengan cukup untuk kondisi belajar.

\section{Perhatian dan kasih sayang.}

Anak tentunya sangat membutuhkan perhatian dan kasih sayang dari orangtuanya sebab hal itu sangat penting untuk menciptakan mood belajar pada anak yang sangat berperan penting didalam mendukung suatu keberhasilan anak dalam menjalani proses pendidikan. Perhatian yang sederhana namun sangat besar manfaatnya untuk anak ialah sebagai berikut contohnya, ketika anak mengalami suatu kesulitan dalam kegiatan belajar, orangtua dengan sigap mencari dan memberikan solusi atas permasalahan tersebut agar segera teratasi, dan disaat anak mendapatkan suatu masalah dengan temantemannya maka orangtua harus memberikan respon positif tanpa mencampuri secara langsung atas masalah tersebut namun memberikan perhatian dan kasih sayangnya dalam rangka membantu anak untuk menghadapi permasalahn yang dihadapi.

\section{Penanaman budi pekerti.}

Pada zaman sekarang ini ahlak dan budipekerti semakin mengalami erosi sehingga membutuhkan peran orangtua dalam hal penanaman nilai budi pekerti kepada anak karena orang tua berada dilingkungan keluarga yaitu lingkungan terdekat anak yang tentunya lebih memahami karakteristik anak sehingga mampu menentukan strategi maupun cara untuk memberikan pemahaman tentang nilai budi pekerti agar anak memiliki ahlak yang mulia. Seperti yang kita ketahui mengajarkan nilai budi pekerti kepada anak tidak seperti mengajarkan materi matematika sebab yang menjadi target 
dari pemberian pemahaman budi pekerti ini ialah aspek sikap dan perilaku si anak, karena itu banyak hal yang berkaitan dengan nilai-nilai budi pekerti yang harus diberikan kepada anak, seperti etika, sopan santun dalam bertutur berkata, tidak mengucapkan kata-kata yang tidak pantas untuk diucapkan, memberikan sapa dan salam kepada orang lain, selalu rendah hati dengan menghormati dan/atau menghargai orang lain, dan lain sebagainya. Nilai-nilai budi pekerti ini merupakan hal yang penting untuk ditanamkan sejak dini pada diri anak sehingga anak tidak hanya menjadi anak yang cerdas di sekolah, tetapi juga cerdas dalam bersikap, bertingkahlaku dan sopan santun dalam bertutur kata.

\section{B. Media dan Sumber Belajar}

Orang tua siswa hendaknya memahami dan menguasai media dan sumber walaupun untuk dapat menunjang kegiatan belajar dirumah, adapun penjelasan terkait media dan sumber belajar ialah sebagai berikut:

\section{Media Pembelajaran}

Pada awalnya, media pembelajaran digunakan hanya untuk menyampaikan suatu materi kepada peserta didik hanya dalam bentuk materi bahan ajar secara visual. Seiring dengan perkembangan jaman maka meningkat pula perkembangan IPTEK sehingga khususnya pada bidang pendidikan alat bantu dan media pembelajaran telah dimodifikasi mengikuti perkembangan teknologi yang tadinya dalam bentuk visual saja lalu dikombinasikan dengan alat audio sehingga menjadi media audio-visual, hal ini dimulai pada abad ke-20 sebab pada abad tersebut sudah ada usaha pemanfaatan media pembelajaran dalam bentuk visual yang dilengkapi alat audio.

\section{Sumber Belajar}

Jika dipahami secara hakikat bahwa alam semesta ini merupakan sumber belajar walaupun secara ilmiah sumber belajar merupakan semua sumber baik dalam bentuk data, orang dan wujud tertentu yang bisa digunakan oleh siswa untuk menunjang kegiatan belajar, baik secara terpisah atau secara terkombinasi hal ini akan membuat siswa dapat mencapai tujuan belajar maupun tujuan kompetensi tertentu dengan mudah.

Sumber belajar ialah segala sesuatu yang tersedia di lingkungan alam semesta yang dapat digunakan untuk membantu dalam mengoptimalisasi kegiatan belajar dan memaksimalkan hasil belajar siswa. Proses pembelajaran dalam bentuk interaksi antara siswa dengan guru dab berbagai sumber belajar dalam rangka memberikan stimulus untuk minat belajar serta mempercepat siswa memahami dan menguasai bidang ilmu yang dipelajari merupakan salah satu indikator Optimalisasi hasil belajar siswa.

\section{Fungsi Media dan Sumber Belajar}

\section{- Media Pembelajaran}

Berdasarkan ulasan diatas, pengetahuan yang diperoleh siswa semakin bersifat abstrak ketika materi pelajaran hanya diberikan dengan bahasa verbal. Jika hal itu dibiarkan 
berlarut-larut maka kemungkinan terjadinya verbalisme tidak dapat dihindari, verbalisme yang dimaksud dalam penelitian ini ialah dimana peserta didik mengetahui sebatas kata tanpa mengetahui dan memahami makna dari kata tersebut. Selain itu, ketika informasi hanya disampaikan secara verbal maka hal itu akan menurunkan semangat peserta didik untuk menyerap dan menerima informasi atau pesan yang disampaikan pada saat kegiatan pembelajaran. Karena idealnya agar siswa dapat memahami suatu pesan atau informasi yang disampaikan oleh pendidik maka siswa harus terlibat fisik maupun psikis secara langsung, tetapi pada kenyataannya, memberikan pengalaman secara langsung pada peserta didik bukanlah sesuatu hal yang mudah, sebab seerti yang kita ketahui bahwa tidak semua pengalaman bisa secara langsung dipelajari oleh peserta didik. Contoh, jika guru akan menyampaikan materi tentang kondisi permukaan bulan, maka suatu hal yang tidak mungkin untuk seorang guru mengajak siswanya untuk langsung observasi kebulan. Dengan demikian media pembelajaran memiliki peran yang sangat penting dalam suatu kegiatan pembelajaran. Didalam kegiatan belajar Pendidik dapat menggunakan media belajar dalam bentuk alat pemancar gambar ataupun audio visual seperti proyektor yang dihubungkan dengan perangkat computer atau laptop, TV atau gambar dalam menyampaikan informasi pada peserta didik. Dengan memanfaatkan kecanggihan teknologi pendidik dapat menggunakan media pembelajaran audio-visual untuk dapat membuat hal yang bersifat abstrak menjadi lebih konkret.

Jika dilihat dari segi fungsi berikut fungsi media secara umum, diantaranya:

a. Media dapat mengatasi masalah keterbatasan atas pengalaman yang dimiliki oleh para peserta didik. Karena seperti yang kita ketahui bahwa terdapat keaneka ragaman atas pengalaman yang dimiiki oleh siswa, hal itu diakibatkan oleh pengaruh dari unsur yang mampu menentukan peningkatan atas pengalaman siswa, contohnya; kesempatan berwisata, ketersediaan buku, dan sebagainya. Hal itu dapat diatasi dengan memanfaatkan media pembelajaran. Jika situasi kondisi obyek yang sulit untuk dijangkau oleh siswa dalam rangka pengamatan secara langsung untuk dipelajari, maka obyek yang akan dipelajari tersebut yang akan dibawa ke siswa.

b. Karena adanya keterbatasan ruang kelas maka terjadi permasalahan dimana para peserta tidak dapat mengamati suatu objek secara langsung didalam kelas, hal itu, karena obyek terlalu:

- kecil,

- besar;

- cepat;

- lambat;

- halus

- kompleks; 
c. Menyebabkan terjadinya kontak langsung diiantara siswa dengan lingkungannya.

d. menimbulkan suatu keseragaman pada saat penyelidikan

e. Menanamkan suatu konsep bersifat prinsip pada sesuatu yang bersifat benar, realistis, dan konkrit,.

f. Membangkitkan suatu keinginan ataupun minat baru pada siswa.

g. Membangkitkan semangat belajar siswa melalui rangsangan ataupun memberikan motivasi.

h. Memberikan suatu pengalaman yang bersifat menyeluruh dimulai dari yang bersifat konkrit sampai dengan yang bersifat abstrak

\section{Media dan Sumber Belajar Via Daring}

Menurut Hadiapurwa dan Novian (2021), menyampaikan bahwa Kementerian Pendidikan telah memberikan himbauan kepada seluruh lembaga pendidikan dibawah naunganya untuk melaksanakan kegiatan pembelajaran secara online sesuai yang termuat didalam Surat Edaran Menteri Pendidikan dan Kebudayaan Republik Indonesia Nomor 4 Tahun 2020 tentang Pelaksanaan Pendidikan dalam Masa Darurat Coronavirus Disease (COVID19). Keadaan ini menyebabkan, sebagian besar peserta didik mengalami kesulitan untuk ikut serta dalam kegiatan pembelajaran secara daring karena keterbatasan dari segi sumber belajar elektronik. Berdasarkan dari masalah tersebut, maka dirasa perlu eksistensi perpustakaan digital yang menjadi salah satu sumber belajar yang efektif dan efisian bagi siswa guna mengoptimalkan kegiatan pembelajaran via daring.

Seperti yang disampaikan oleh Fathonah dan Bukhori, (2021). Cara yang harus ditempuh oleh siswa untuk mengatasi permasalahan tersebut ialah dengan mengakses informasi terkait materi belajar melalui mesin pencari yang tersedia di internet, alternative lain ialah dengan bertanya kepada guru, orang tua ataupun teman sekelas, serta berusaha secar mandiri mencari solusi atas permasalah tersebut seperti misalnya mencari tempat yang tenang dan kondusif dan jika tidak memiliki kuota data internet maka bisa meminta bantuan sandingan paket data kepada orang tua atau keluarga terdekat yang kiranya dapat memberikan bantuan tersebut. Sehingga dari pembahasan ini kita dapat pahami bahwa terdapat beberapa faktor eksternal dan faktor internal yang dapat menghambat siswa dalam mengikuti kegiatan belajar via daring.

Menurut kuriawansyah dan siswanto (2020), dalam jurnalnya yang berjudul Kolaborasi Whatsapp Group, Zoom Cloud Meeting, dan Google Drive Sebagai Formula dalam Pelaksanaan Kegiatan Perkuliahan Online di Masa Pandemi Covid-19. Mengatakan bahwa pada saat ini Dunia Pendidikan dihadapkan pada suatu tantangan besar dengan adanya kasus Pandemi Covid-19. Hal ini memberi dampak pada setiap lini pendidikan sehingga pelaksanaan belajar yang biasanya dengan tatap muka dikelas, untuk saat situasi kondisi pandemi ini dilarang dan guru harus melakukan kegiatan pembelajaran secara daring. 
Dengan demikian membuka peluang bagi para programmer untuk berkreatifitas dan menuangkan idenya dalam bentuk Aplikasi sehingga selama masa pandemi ini banyak muncul aplikasi yang dapat mendukung kegiatan pembelajaran daring seperti; Whatsapp Group, Google Drive, Zoom, Google Meeting, dan lainlain. guru dan siswa dituntut untuk tidak boleh gagap teknologi, sebab jika salah satu diantaranya ada yang tidak bisa memanfaatkan Teknologi, maka kegiatan pembelajaran secara daring tidak akan dapat berjalan dengan lancar sehingga akan menjadi sangat sulit untuk melaksanakan kegiatan pembelajaran secara daring. Dampak yang sangat jelas terlihat dari pandemi COVID-19 ialah perubahan teknis pada sistem pelaksanaan pembelajaran disekolah yang tadinya via luring beralih menjadi via daring. Tidak semua sekolah dapat menyesuaikan atas keadaan ini sehingga Bagi kebanyakan sekolah membutuhkan penyesuaian untuk bisa mengikuti sistem pembelajaran seperti ini karena terkendala dengan berbagai faktor, termasuk bagaimana cara melatih siswa untuk dapat menjawab soal-soal pertanyaan yang dibagikan pada aplikasi dengan tanpa pengawasan namun mereka dapat dikontrol dalam arti mereka tanpa harus menyontek dengan mencari jawaban pada mesin pencari di situs internet ataupun dengan bantuan orang tua untuk menjawab soal tersebut. Tersedianya media pembelajaran berbasis teknologi yang mampu menunjang pada media yang sudah ada contohnya ialah dalam bentuk e-learning yang sering digunakan pada kegiatan pelatihan ataupun perkuliahan. E-learning merupakan aplikasi yang berbasis onlen yang membutuhkan jaringan internet memiliki fitur yang lengkap untuk menunjang kegiatan pembelajaran sehingga pendidik dan peserta didik seorah berada pada ruang kelas didunia maya walau pada kondisi realnya antara guru dan suswa sedang berada pada tempat yang beerbeda. Elearning didesain sedemikian rupa agar dapat mengatasi segala keterbatasan yang dialami oleh pendidik dan pesrta didik, terutama dari segi kondisi keadaan ruang, jarak dan waktu. Secara singkatnya, aplikasi e-learning ini mampu menciptakan suatu ruang digital yang mendukung kegiatan pembelajaran, dimana siswa dapat mengakses materi pelajaran yang diberikan oleh guru maupun dari berbagai sumber tanpa dibatasi oleh ruang dan waktu. Sehingga masa pandemi Covid-19 hal ini dirasa sangat sangat efektif dan efisien menunjang kelancaran kegiatan pembelajaran secara daring, untuk kegiatan tatap muka tenaga pendidik dan peserta didik dapat memanfaatkan salah satu aplikasi tatap muka didunia maya sepeti misalnya Aplikasi Zoom Meeting.

Dengan demikian peneliti dapat menyimpulkan bahwa dalam situasi menghadapi masa pandemi ini, proses belajar mengajar harus tetap dilaksanakan dengan memanfaatkan aplikasi-aplikasi yang dapat mendukung kegiatan pembelajaran.

1. Adapun tujuan yang mendasari Pelaksanaan Belajar Dari Rumah (BDR) selama masa situasi pemberlakuan darurat Covid-19: 
2. Prinsip Pelaksanaan Belajar Dari Rumah. Kegiatan Belajar Dari Rumah (BDR) dilaksanakan harus sesuai dengan prosedur-prosedur serta syarat ketentuan yang berlaku sesuai dengan Surat Edaran MENDIKBUD RI Nomor 4 Tahun 2020 tentang Pelaksanaan Kebijakan Pendidikan dalam Masa Darurat Penyebaran Corona Virus Disease (Covid-19).

\section{Peran Orang Tua dalam}

\section{Pembelajaran Via Daring}

Pembelajaran daring ialah suau kondisi dimana kegiatan pembelajaran dilakukan di rumah karena tidak bisa dilakukan kegiatan tatap muka langsung dengan guru dikelas, maka dengan demikian peran orangtua siswa di rumah akan menjadi seorang pembimbing siswa agar siswa dapat memahami atas materi yang diberikan guru dengan baik. Memang akan terasa suasana yang sangat berbeda ketika anak belajar secara langsung tatap muka dikelas dibandingkan dengan belajar secara online. Sehingga secara tidak langsung tugas orangtua bertambah yaitu memastikan bahwa anaknya dapat menyerap ilmu yang diberikan oleh guru secara maksimal. Jangan sampai anak malah tidak bersemangat dan memutuskan untuk tidak melanjutkan sekolah karena situasi dan kondisi pandemi yang menyebabkan kendala siswa dapat tatap muka secara langsung dengan guru dikelas.

Adapaun tindakan yang perlu dilakukan rang tua siswa untuk mendukung kegiatan belajar mengajar anak yaitu:
1. Memastikan kondisi kesehatan anak

Situasi pandemi seperti yang dialami sekarang ini faktor kesehatan merupakan unsur yang bersifat utama yang mesti dijaga sebab ketika kesehatan terganggu maka segala aktifitas juga akan terganggu. Demikian halnya pada proses pembelajaran anak juga akan terganggu jika anak sedang mengalami sakit. Anak akan dapat lebih fokus dan konsentrasi serta menyerap materi pelajaran secara maksimal, jika tubuh anak Kondisi fit. Orang tua tidak boleh lengah dan harus tetap siaga dan waspada mengawasi kondisi keluarga di rumah, sebab kehati-hatian dan kewaspadaan sangat dibutuhkan agar seluruh anggota keluarga selalu dalam kondisi sehat.

Untuk menjamin kesehatan seluruh anggota keluarga terutama pada anak-anak, maka orang tua juga harus komitmen untuk mematuhi protokol kesehatan secara ketat. Orang tua sehabis aktivitas atau berkerja di luar rumah tidak lupa untuk memastikan keadaan dirinya bebas terkontaminasi virus saat tiba dirumah melakukan langkah-langkah membersihkan tubuh ataupun pakaian yang digunakan saat bekerja diluar rumah. Orangtua juga harus memperhatikan keseimbangan nutrisi, asupan gizi, vitamin dan mineral pada makanan yang dihidangkan untuk keluarga. Dan yang utama ialah kondisi keluarga terjamin dan berada pada kondisi bahagia agar dapat menjaga imunitas tubuh tidak turun sehingga tidak mudah terserang penyakit.

2. Menyediakan fasilitas yang
dibutuhkan saat belajar 
Tidak dapat dipungkiri bahwa dibutuhkan alat yang memadai untuk mendukung seperti laptop, smartphone, atau personal computer (PC) dalam pelaksanaan praktik pembelajaran secara daring yang diberlakukan selama masa pandemi. Selain itu juga diperlukan faktor penunjang lainnya yaitu signal, paket kuota internet serta sarana dan prasarana belajar lain seperti alat tulis dan buku mata pelajaran. Terkadang seiring berjalannya kegiatan pembelajaran dibutuhkan alat dan bahan khusus yang harus disiapkan agar kegiatan pembelajaran dapat berjalan dengan lancar.

\section{Memberikan suasana nyaman dalam belajar}

Pelaksanaan pembelajaran secara online terdapat perbedaan yang sangat besar dibandingkan dengan kegiatan pembelajaran yang dilaksanakan dengan tatap muka dikelas. Pembelajaran yang dilakukan di sekolah tentunya didukung oleh suasana belajar yang kondusif sebab kondisi suasana belajar secara otomatis terbentuk karena sekolah memang tempat yang diseting secara khusus untuk melaksanakan kegiatan proses pembelajaran. Berbeda halnya dengan suasana dan kondisi belajar di rumah sanagt berbeda dengan situasi dan kondisi belajar di sekolah sehingga menjadi suatu tantangan dalam melaksanakan proses pembelajaran yang kiranya perlu perhatian lebih serta dicarikan solusi pemecahan masalah oleh orang tua siswa.

Suasana dan kondisi ruang belajar yang nyaman sangat dibutuhkan anak saat belajar daring agar anak dapat fokus menerima dan menyerap materi pelajaran. Jadi tugas orang tua ialah memastikanagar anak pada saat kegiatan belajar berada pada suasana yang mendukung, dengan demikian orang tua siswa perlu untuk memastikan ruangan belajar anaknya agar tetap terlihat rapi dan bersih, serta memiliki pencahayaan yang baik, serta juga memperhatikan sirkulasi udara diruang belajarnya agar tetap lancar karena asupan oksigen sangat diperlukan pada kegiatan belajar ataupun proses berpikir anak. Orang tua harus dapat menyediakan segala kebutuhan yang diperlukan saat anakmengikuti proses seperti perlengkapan belajar, alat tulis, buku, dan juga air minum ada dalam jangkauan anak karena air mengandung oksigen yang dapat memenuhi kandungan osigen pada anak agar tidak dehidrasi pada saat proses belajar karena hal itu akan mempengaruhi konsentrasi dan fokus anak.

4. Menjadi teladan bagi anak

Perlu dipahami dan diketahui oleh sorang tua siswa bahwa mendidik anak bukanlah serta merta hanya menyediakan fasilitas dan suasana ruang belajar yang nyaman. Orang tua siswa hendaknya dapat memberikan contoh yang baik serta dapat memberikan kata-kata positif kepada anak untuk memotivasi anak agar tetap semangat belajar. Kendala sering dialami pada saat kegiatan pembelajaran secara daring ialah kurangnya student's engagement atau yang dikenal dengan istilah keterlibatan siswa. Hal ini dapat dikarenakan oleh rasa bosan atau faktor 
lain yang membuat perhatian siswa teralihkan pada saat proses pembelajaran misal tayangan televisi atau HP.

Ketika orang tua akan memberlakukan sebuah peraturan di rumah, hendaknya orang tua terlebih dahulu memastikan bahwa ia bisa menjadi contoh terhadap contoh yang diberikan dalam arti orang tua juga harus komutmen itu menjalankan aturan tersebut. Misalnya ketika orang tua melarang anak bermain Handphone saat belajar, maka pada saat itu orang tua juga tidak boleh sibuk bermain Handphone. Begitu halnya dalam memanajemen waktu, memelihara kebersihan lingkungan tempat tinggal, dan sikap orang tua kepada anak, sehingga dapat disimpulkan orang tua semestinya menjadi contoh yang baik bagi anak. Sikap dan karakter anak di rumah akan tercermin pada sikap dan prilaku belajar anak juga.

\section{Memberikan pendampingan saat} belajar

Orang tua harunsya memiliki sikap yang perhatian dan tidak boleh cuek terhadap anak ketika anak sedang melaksanakan kegiatan pembelajaran secara daring. Tidak dapat dipungkiri bahwa Pendampingan dari orang tua sangat diperlukan pada saat pembelajaran daring sebab saat itu wali murid ialah mitra utama tenaga pendidik. Partisipasi orang tua dalam kegiatan pendampingan dapat dalam bentuk pemberian kata-kata motivasi, mereview materi yang diberikan oleh guru dan mengingatkan tugas-tugas yang telah diberikan oleh pendidik, dan memberikan bimbingan terhadap hal-hal yang kurang dipahami oleh anaknya.

Sering terjadi kesalah pahaman atas maksud dari bimbingan dan pendampingan orang tua pada anak sebab hal itu sering disalah artikan bahwa orang tua membantu mengerjakan bahkan mengerjakan secara langsung atas tugas-tugas yang diberikan oleh guru kepada anaknya agar anaknya mendapatkan nilai yang maksimal. Seharusnya orang tua memahami terkait pendampingan yang dimaksud disini ialah dalam bentuk tindakan yang dapat meningkatkan motivasi belajar anak dan membangun kepercayaan diri anak sehingga anak berpikir dan memiliki keyakinan bahwa bahwa ia bisa mandiri. Dengan penjelasan tersebut diatas maka hal ini perlu untuk dimengerti serta dipahami oleh orang tua siswa dikarenakan pemahaman yang benar atas pendampingan merupakan salah satu usaha orang tua agar dapat mencapai suatu keberhasilan dalam mendidik anak.

\section{Berkoordinasi dengan guru}

Salah satu unsur penting yang dapat mendukung kelancaran koordinasi wali murid dengan guru adalah komunikasi, sehingga diharapkan Orang tua siswa dapat menjalin hubungan komunikasi yang baik dengan guru sehingga kerjasama akan terbina dengan baik hal itu akan membawa dampak positif kepada anak sebab hal itu akan mendukung kesuksesan kegiatan pembelajaran secara daring. Adapun Bentuk koordinasi yang umum dilakukan oleh orang tua siswa dengan guru ialah penyampaian terkait kendala yang 
mungkin akan atau telah dihadapi oleh anak saat kegiatan pembelajaran baik disekolah maupun dirumah, menanyakan perkembangan yang dialami oleh anak pada saat proses belajar, dan lain sebagainya. Dengan adanya koordinasi antara orang tua siswa dan guru maka akan tercipta suasana saling mengerti saling memahami dan saling berempati sehingga komunikasi akan dapat terjalin secara intens dan berjalan dengan lancar serta berhasil baik. Peran orang tua sebagai wali murid dalam kegiatan pembelajaran yang dilakukan secara online akan berjalan secara optimal ketika adanya kerjasama yang terjalin dengan baik dari berbagai belah pihak maka hal itu dapat mempermudah dalam mencapai tujuan suatu pembelajaran

\section{SIMPULAN}

Berdasarkan hasil observasi, dan wawancara di lokasi penelitian bahwa pendidikan yang biasanya dilaksanakan secara tatap muka dikelas, selama masa pandemi menjadi tatap muka secara Online.

Begitu juga walau saat sudah mulai diberlakukan tatap muka disekolah atau istilahnya via luring siswa mendapatkan jatah waktu yang sangat sedikit dan jadwal sekolah yang tidak seperti biasanya dengan tetap memberlakukan protokol kesehatan hal itu sangat mempengaruhi optimalisasi penyampaian materi guru dikelas sehingga anak dibebankan untuk lebih banyak belajar dirumah terhadap materi yang telah disampaikan oleh guru saat tatap muka dikelas ataupun via daring. Sehingga hal itu akan berpengaruh pada tugas dan tanggungjawab orang tua sebab anak tentunya tidak akan bisa secara maksimal belajar sendiri dirumah tanpa peran serta orang tua, begitu juga orang tua tentunya secara tidak langsung dituntut untuk dapat memahami teknik, strategi dan alat/media serta sumber belajar secara online agar mampu mendukung dalam hal pendampingan kepada anak saat belajar dirumah.

Orang tua siswa juga secara tidak langsung dituntut memiliki prangkat elektronik dan tidak hanya itu orang tua dan siswa juga dituntut untuk mahir menggunakan alat dan teknologi tersebut, khususnya mahir dalam menggunakan aplikasi yang didukung oleh layanan data internet minimal aplikasi yang ada pada handphone android sebab materi pelajaran yang diberikan oleh guru di disampaikan dan bagikan pada media aplikasi seperti Whatsapp group, Zoom Meeting, Google Class Room, dan aplikasi lainnya, sehingga orang tua atau peserta didik yang tidak memiliki fasilitas dalam bentuk sarana dan prasarana tersebut tidak dapat secara maksimal melakukan pendampingan terhadap anak saat kegiatan pembelajaran secara daring, sehingga anak akan menjadi ketinggalan materi pembelajaran yang disampaikan oleh guru.

Faktor-faktor distorsi yang dialami siswa seperti masalah signal, situasi tempat belajar yang tidak 
kondusif karena suara bising, dapat mengganggu fokus dan konsentrasi anak saat belajar, selain itu faktor keterampilan dan kreatifitas guru sangat diperlukan baik dalam hal mengoprasikan aplikasi pendukung pembelajaran via daring ataukah disain dan strategi pembelajarannya harus dapat menarik minat anak usia dini untuk ikut serta dalam proses pembelajaran sebab penyampaian materi tidak akan dapat dikatakan berhasil jika tidak ada feedback atau interaksi antara peserta didik dan pendidik saat kegiatan mengajar, sehingga kualitas penyerapan materi siswa menjadi tidak maksimal.

Masalah ini menimbulkan pekerjaan tambahan bagi orang tua dirumah untuk menjelaskan dan memberikan pemahaman ulang kepada anaknya terkait materi tersebut sehingga orang tua siswa harus memiliki ilmu pengetahuan, dan keterampilan untuk mendukung keberhasilan orang tua dalam melaksanakan tugas tersebut.

Walaupun Media pembelajaran dianggap hanya sebatas alat bantu bagi guru untuk menyampaikan materi namun hal itu merupakan aspek yang sangat penting sebab jika guru tidak mampu atau tidak mahir dalam menggunakan media pembelajaran maka pesan atau informasi terkait materi tidak akan dapat disampaikan secara efektif dan efisien, sebab tidak semua guru mampu menggunakan media dan sumber belajar yang saat ini sudah dapat dikatakan canggih yaitu

media pembelajaran yang menggunakan perpaduan antara audio-visual. Sumber belajar merupakan kumpulan bahan yang diperlukan untuk diberdayagunakan pada suatu kegiatan pembelajaran. Di era pandemi hingga pasca pandemi ini guru tetap dituntut untuk mahir dan bisa membiasakan diri dalam menggunakan serta membuat media dan sumber belajar yang dapat menunjang keberhasilan pendidikan baik secara online maupun offline.

Pendemi Covid-19 membuat pemerintah harus melakukan beberapa kebijakan darurat salah satunya adalah Belajar Dari Rumah (BDR). Pada kegiatan BDR, orang tua sebagai jembatan pengetahuan dari guru ke anak, sehingga orang tua memiliki peran penting pada proses pembelajaran Via daring maupun membentuk karakter sikap anak agar siap mengawali pembelajaran via Luring.

Orang tua dan guru diharapkan memiliki komunikasi yang baik agar terdapat hubungan yang sinergi didalam proses belajar mengajar, pelaksanaan belajar via daring menimbulkan berbagai tantangan dan hambatan sehingga menuntut guru agar meningkatkan mutu dan kualitas dalam penyampaian materi sebab tidak semua orang tua siswa mau, mampu dan sadar untuk ikut berperan serta didalam mendukung kelancaran siswa dalam menyerap materi yang disampaikan oleh guru, sebab kenyataannya bahwa siswa yang masih 
dijenjang Usia dini tidak akan mungkin bisa melaksanakan kegiatan pembelajaran secara mandiri via daring sehingga butuh pendampingan dari orang tua namun kenyataan dilapangan berbeda dimana ada beberapa orang tua memiliki pemahaman yang keliru terkait pendampingan tersebut sehingga mereka menganggap bahwa mengerjakan pekerjaan yang diberikan kepada anak adalah suatu hal yang sahsah saja sehingga tigas dan pekerjaan anak diselesaikan oleh orang tua dengan tujuan agar anak mendapatkan nilai yang baik. Selain itu faktor kurangnya keterampilan, pengetahuan dan kemampuan guru dalam mengoprasikan media sumber belajar elektronik membuat seorang guru tidak maksimal dalam memberikan ataupun menyampaikan materi sehingga guru cenderung hanya menggunakan aplikasi Whatsapp group untuk memberikan pesan dan informasi kepada orang tua agar menyampaikan materi mana yang ada didalam buku panduan belajar yang harus dipelajari anak.

\section{DAFTAR PUSTAKA}

Abimanyu, Soli. dkk. 2008. Strategi Pembelajaran. Jakarta: Direktorat Jendral Pendidikan Tinggi Departemen Pendidikan Nasional.

Hadiapurwa, A., Novian, R. M., \& Harahap, N. (2021). Pemanfaatan Perpustakaan Digital Sebagai Sumber Belajar Elektronik Pada Masa
Pandemi COVID-19 Di

Tingkat SMA. Jurnal

Penelitian Pendidikan, 21(2),

36-48.

https://doi.org/10.17509/jpp .v21i2.38526

Lalu, KH Gede Muhammad Zainuddin Atsani. (2020). Transformasi

Media Pembelajaran Pada

Masa Pandemi Covid-19. Vol. 1 No. 1 (2020): Januari - Maret. Afni, Nur dan Jumahie. Peran Orang Tua dalam Meningkatkan Prestasi Belajar Anak. Vol. 12 No. 1 (2020). https://doi.org/10.24239/ms w.v12i1.591

Lexy J. Moeleong. (2019). Metode Penelitian Kualitatf: Edisi Revisi.

Bandung : Remaja Rosdakarya

Megawangi, Ratna. (2004). Pendidikan

Karakter.Jakarta: Indonesia

Heritage Fondation.

Muri'ah Siti. (2011). Nilai-nilai Pendidikan Islam dan Wanita

Karier. Semarang: RASAIL Media Group

Saleh, Abdurahman, dkk. (2004). Psikologi Suatu Pengantar dalam Perspektif Islam. Jakarta: Kencana.

Sari, Ajeli A.P. (2021). Penerapan NilaiNilai Moderasi Beragama Pada Pendidikan Anak Usia Dini Melalui Pendidikan Agama Islam. Bengkulu: Institut Agama Islamnegeri (IAIN) Bengkulu.

Sudaryono, (2014). Educational Research Methodology. Jakarta Pusat: Lentera Ilmu Cendikia

Sugiyono. (2010). Metode Penelitian Kuantitati Kualitatif Dan RED. Bandung: ALFABETA

Sutarjo Adisusilo, J.R. (2012). Pembelajaran Nilai-nilai 
Karakter Konstruktivisme dan

VCT Sebagai Inovasi

Pendekatan Pembelajaran

Afektif. Jakarta Pusat:Rajawali pers.

Valeza, A. S. (2017). Peran orang tua dalam meningkatkan Prestasi anak di perum tanjung raya permai kelurahan pematang wangi kecamatan tanjung senang bandar lampung. Skripsi, 106. Retrieved from http://repository.radenintan. ac.id/id/eprint/2331 https://www.amongguru.co $\mathrm{m} /$ media-pembelajarandaring-online-programbelajar-dari-rumah/

Fathonah, U., \& Bukhori, H. A. (2021). Analisis Kesulitan Siswa Dalam Pelaksanaan Pembelajaran Bahasa Jerman Secara Daring Selama Pandemi Covid-19 Di Sekolah Menengah Atas. EDUKATIF : JURNAL ILMU PENDIDIKAN, 3(4), 11521160. Retrieved from https://id-theasianparentcom.cdn.ampproject.org/v/s $\lfloor$ id.theasianparent.com/pera n-orangtuabelajardaring/amp?amp_js_v $=a 6 \& a m p \_g s a=1 \& u s q p=m q 33$ 1AQKKAFQArABIIACAw\%3 D\%3D\#aoh $=16405678865395 \&$ referrer $=$ https $\% 3 \mathrm{~A} \% 2 \mathrm{~F} \% 2 \mathrm{Fw}$ ww.google.com\&amp_tf=Dari $\% 20 \% 251 \% 24$ s\&ampshare $=$ htt ps $\% 3 \mathrm{~A} \% 2 \mathrm{~F} \% 2 \mathrm{Fid}$.theasianpar ent.com $\% 2$ Fperan-orangtuabelajar-daring

Islamay,Elsya. (2021). https:/ / www. gramedia. com/literasi/jenisjenis-penelitian/ 